\title{
FutureJournal
}

\section{The Insertion of the Tool Balanced Scorecard in the Strategic Planning of a Growing Company: A Case Study in the Company Metadil Metalúrgica Indústria e Comércio Ltda}

\author{
Rafaela Thomaz Queiroz \\ Graduate Student in Administration from University Nove de Julho (UNINOVE), Brazil \\ rafaelatqueiroz@hotmail.com
}

\author{
Antonio Lobosco \\ PhD in Administration from University Nove de Julho (UNINOVE), Brazil \\ antoniolobosco@hotmail.com \\ Martinho Isnard Ribeiro de Almeida \\ PhD in Administration from University of São Paulo (USP), Brazil \\ martinho@usp.br \\ Emerson Antonio Maccari \\ PhD in Administration from University of São Paulo (USP), Brazil \\ emersonmaccari@gmail.com
}

\section{ABSTRACT}

The aim of this study was to analyze how the Balanced Scorecard (BSC) can assist in the building the strategic planning of a small growing company, in order to achieve its strategic targets. For this purpose, it was carried out a study in a small company of the furniture segment, with a view to identify the benefits derived from the use of BSC at the organization. The following departments were analyzed: Human Resources, Marketing/Customers, Finances, and Production, and identified as BSC perspectives, they assisted in meeting the strategic targets of the company. In this study, it was adopted the qualitative methodology, with exploratory and descriptive nature, through case study. By the close analysis of BSC use, it was noticed, that there should be greater interaction among the different areas, with effective acting from HR area, regarding improvement in the company learning and growth, such as training and motivation programs; at the Production section, indicators were created in order to meet the increasing demand; concerning Marketing/Customers section, it was identified, through indicators at customers perspective, their real needs, in order to keep them satisfied with products and services; and, regarding to Finances, indicators were 


\section{FutureJournal}

created to manage the investments and the minimization of production costs.

KEY-WORDS: Strategic Planning. Balanced Scorecard. Strategic Map. Expanding Small Company.

\section{A Inserção da Ferramenta Balanced Scorecard no Planejamento Estratégico de uma Empresa em Crescimento: Um Estudo de Caso na Empresa Metadil Indústria e Comércio Metalúrgica Ltda}

\section{RESUMO}

O objetivo deste trabalho foi analisar como o Balanced Scorecard (BSC) pode auxiliar na construção do planejamento estratégico de uma pequena empresa em fase de crescimento para que seus objetivos estratégicos sejam atingidos. Para tanto, elaborou-se um estudo em uma pequena empresa do setor moveleiro com o objetivo de identificar os benefícios oriundos do uso do BSC na organização. Analisaram-se os departamentos de Recursos Humanos, Marketing/Clientes, Financeiro e Produção, e identificou-se como as perspectivas do BSC auxiliaram no cumprimento dos objetivos estratégicos da empresa. A metodologia adotada neste estudo foi qualitativa de caráter exploratório-descritivo por meio de estudo de caso. Pela utilização do BSC, percebeu-se que deveria haver maior interação entre as áreas com efetiva atuação da área de $\mathrm{RH}$ em relação às melhorias referentes ao aprendizado e ao crescimento na empresa, tais como treinamentos e programas motivacionais; no setor de Produção, foram criados indicadores para atender ao aumento da demanda; quanto à área de Marketing/Clientes, identificaram-se, por meio de indicadores na perspectiva do cliente, as reais necessidades dos clientes para mantê-los satisfeitos com os produtos e serviços; quanto à área financeira, criaramse indicadores para administrar os investimentos e minimizar os custos produtivos.

PALAVRAS-CHAVE: Brazilianness. National Identity. Brazilian Culture. Brazil's Image. 


\section{INTRODUCTION}

Hitt, Ireland and Hoskisson (2001) define innovation as the key outcome that companies seek through entrepreneurship and that it is often the source of competitive success for companies that compete in a global economy. According to the authors, innovation arises from the entrepreneurial spirit in the most different situations and locations. Companies and their managers seek through the entrepreneurial spirit, ensure the organization competitiveness. When analyzing the concept origins, Fillion (1999) and Hisrich and Peters (2002) emphasize that the term "entrepreneur" has been already used since the Middle Ages to describe either a player or a person who manages large production projects (building of castles, forts, etc.). It is considered in general that entrepreneurial characteristics are important to differentiate the companies and support them, leading them to their development and to their survival in a competitive market.

Over the years, entrepreneurs have realized the need to use the strategic planning in order to stay in the market and prosper in business, analyzing the environments that surround them and promoting innovative aspects to its management process.

There are several strategic planning definitions. To Fischmann and Almeida (2009, p. 25),

Strategic planning is a management technique that, through the analysis of an organization's environment, creates awareness of its opportunities and threats, its strengths and weaknesses for its mission fulfillment and, through this awareness, establishes the direction purpose the organization should take to seize opportunities and reduce risks.

Almeida (2001, p. 13) adds the character of "ordering of ideas and people, in order to create a vision of the path that must be followed".

Generally speaking and regardless of the methodology used, some basic aspects should be considered in any planning. Ackoff (1974, p.4) presents five parts of the strategic plan: 
1. The purposes planning: specification of the desired future scenario, namely the mission, the purposes, the objectives, the sectorial objectives or the challenges and the goals.

2. The means planning: path proposition for the company achieve the desired future scenario, for example, through the expansion of productive capacity of a unit and / or te product diversification. Herein there is the choice of macro strategies, macro policies, strategies, policies, procedures and practices.

3. The organizational planning: layout of the organizational requirements in order to carry out the proposed means. Here one can have, for example, the company's structuring in strategic business units.

4. The resources planning: dimensioning of human and material resources, determination of the sources and uses of funds. Here one can have the establishment of programs, projects and action plans needed to achieve the desired future.

5. The deployment and control planning: it is the activity of planning the venture deployment management.

Mintzberg (2008) presents three reasons that justify the importance of the strategic planning development:

1. organizations must plan so that the coordination takes place in their activities;

2. to ensure that the future is taken into consideration and in order to be prepared for the inevitable, organizations must anticipate the unwelcome and control what is controllable;

3. whenever planning the organizations become more rational and more controlling.

In this case study, the strategic planning will be supported in the Balanced Scorecard tool, known as BSC and developed by Kaplan and Norton (1992) to correct a problem concerned to the performance evaluation of organizations: according to the authors, due to the increasing importance of management and of the intangible assets exploitation only the financial indicators would not reflect the activities that create the companies' value. The BSC allows the company to follow-up the short-term 
financial results while monitoring the progress on capacity development and intangible assets that foster the future financial performance.

This tool involves observing the organization in its entirety and is divided into four analytical perspectives (Kaplan \& Norton, 1997): financial perspective, customer perspective, internal processes perspective and learning and growth perspective. The strategic map is the visual sample of the strategy, presenting the objectives and the interaction of the BSC four perspectives (Igarashi, Igarashi, Gasparetto \& Martins, 2008). The company Metadil Indústria e Comércio Metalúrgica Ltda. has made use of this tool to improve its performance indicators and set goals, as well as to improve its controls.

In summary, the BSC translates the vision and the strategy into objectives and performance measures through a balanced set of perspectives; it also includes measures of the desired results and the processes capable of ensuring the achievement of these future goals.

In this article it was aimed to analyze how the company has inserted the BSC tool in this process, considering that Metadil is expanding in its market sector and search performance improvements and strategic controls.

Metadil Indústria e Comércio Metalúrgica Ltda operates in the school and office furniture sector. The furniture industry is characterized by several aspects, such as intensity of manpower use and use of animal or vegetable materials origin. The national furniture industry is allocated mainly in the South and Southeast regions of the country, being $23 \%$ only in the state of São Paulo, where there are two furniture manufacturers poles - the great São Paulo, which specializes in office furniture, and the northwestern São Paulo where it prevails the rectilinear furniture in series, for the domestic market (Rosa Correa, Lemos \& Barroso, 2007).

The furniture sector has been growing in recent years, mostly because of the upturn in the real estate sector in the state of São Paulo and even because of the search for financing from the BNDES (National Bank for Economic and Social Development) in order to purchase machinery and working capital for micro, small and medium sized companies. This 
economy sector, according to the BNDES, is comprised of around 50,000 companies (Rose et al., 2007).

In this work it was sought, in general terms, to present how the BSC has helped the strategic planning development of a small company in the furniture sector under expansion, showing the strategic controls created in each BSC perspective, as well as to expose the strategic map presented to the employees and to the company's governing body for raising awareness and engagement of everybody in face of the strategic goals set by the organization.

Briefly, the main results achieved with the implementation of the Balanced Scorecard in the company were as follows:

A- Financial perspective: in the latest planning, indicators and performance measures have been set so that the revenues reached an increase of $10 \%$ compared to the last period; the company also presented a cost reduction forecast for the next period.

B- Perspective of internal processes: it was noticed in the company the need to improve some processes and organizational structure. The ISO standards deployment is planned to guarantee the products quality for the customers, the automation of processes and also the production increase.

C- Customer perspective: the company constantly seeks a close relationship with its customers, carrying out customer satisfaction surveys in order to understand their needs and the aspects to be reviewed and improved. These indicators have been improved with the use of indicators proposed by the BSC customers' perspective, making the retention and customer loyalty achievable by the organization.

D- Learning and growth perspective: due to seasonality in the sales of its products, the company constantly seeks not only innovations for products creation, but also to meet the needs of specific customers. Indicators on learning and organizational growth have been implemented in order to identify how many innovations have originated from the company's employees ideas and what training programs and courses were made available by the company. It was also analyzed the academic degree and 
professional training of its staff and the amounts invested in the courses conducted by the company.

After these analyzes, through the creation of a strategic map made available to employees, it were presented the indicators, the performance measures and the targets established by the company to its next period.

Overall, the contribution of this paper is to present to small companies how they can enhance their process management using a tool that enables them to create indicators and performance measures and also monitor their business, allowing an improved monitoring on the part of managers, in an organized and segmented way, of their company large areas: finance, production, marketing and human resources. In addition, the BSC allows them to present the organizational goals to the employees and seek their commitment towards the established organizational goals.

\section{THEORITICAL FRAMEWORK}

To Lacombe (2009, p. 98), the Industrial Revolution was a milestone for the enterprises management, due to the emergence and development of the industrial company. The organizations grew and during that period there were great changes in both industry and agriculture, with significant increases in productivity of both, reflecting in the enlargement of trade and financial services and in the corresponding increase in the organizations complexity. This complexity, due to the great innovations that arise in the industries, created the need to study more deeply the business organizations and the best ways for them to reach satisfactory results, turning the planning an indispensable element for entrepreneurs.

Maximiano (2010, p. 81) defines the planning process as:

"- To define objectives or results to be reached, as well as the means to achieve them;

- To imagine a future scenario and work to build it".

To Maximiano (2010, p. 95 and 96), strategy applies to competition cases, i.e. to any action involving the definition of a path to be followed for achieving a target and the choice of how to perform it. 
Strategy is the way to reach a target. It can be inferred from this definition that, for creating a strategy it is also necessary to create a planning or a strategic planning. Thus, the strategic planning plays a fundamental role in coordinating the company, so that the objectives are reached in the best possible way.

The strategic planning in this research will be based in the BSC tool involving the analysis of four areas - Marketing, Production, Human Resources and Finance - of Metadil Indústria e Comércio Metalúrgica Ltda., aiming at their improvement and also making the company more competitive.

\subsection{STRATEGIC PLANNING}

Hayden (1986) cites that strategic planning is a discipline to which an organization submits with greater or lesser degree of formality to determine explicitly what it shall do in the future. Its goal is to enhance the economic and / or social value for its shareholders and define how to best use the organization's resources within its ecosystem.

According to Maximiano (2010, p. 96), strategic planning is the process of structuring and explaining the organization's paths and the objectives it must achieve. The planning process applies to the organization in all its context or corporate strategy, as well as in its offices.

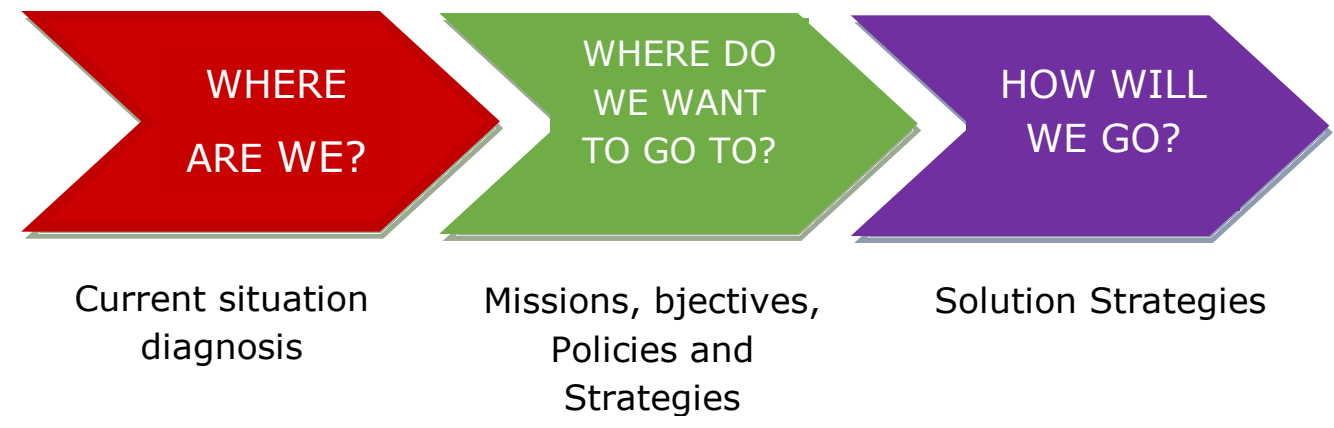

\section{Figure 1: Strategic planning}

Source: Adapted from Oliveira, Perez and Silva (2011)

Figure 1 shows that the strategic planning helps to determine what the company current position is, starting from its current diagnosis; where 
the company wants to reach, determining its mission, its objectives, its operation policies and its business strategies; and how it intends to achieve its future goals (Maximiano, 2010).

Souza and Marinho (2014) mention that the first activity for the strategic planning drafting is to turn the entrepreneur conscious of the need for reflection on the current organization situation and the future plans definition, so as to define its action plans. Starting from the moment the entrepreneur becomes conscious of the planning value and is ready to use part of his time in this action, the authors developed a practical roadmap for its development: I- the mission, the values and the company vision establishment; II- strategic diagnosis; III- of objectives and business goals definition; and IV- strategy definition.

For Fischmann and Almeida (2009), the strategic planning is a technique that can and must be used by small sized companies. It is a technique that can assist in the business targeting of small and medium sized companies, enabling the owners and managers to understand their environment, to strengthen the strengths and reduce the risks, besides enabling these companies to make more assertive decisions and be better prepared for the future.

A systematic planning process is a sequence of analyzes and decisions that comprises the following components:

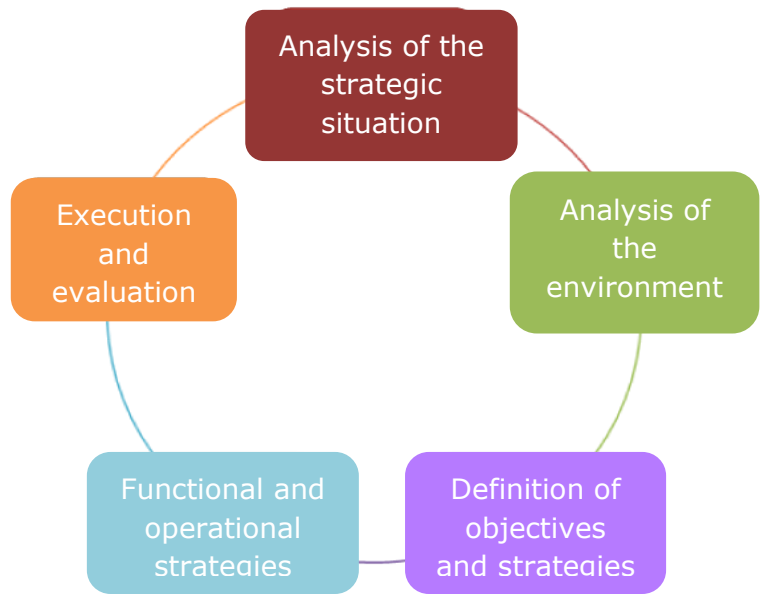

Figure 2: Strategic Planning Process

Source: Maximiano (2008) adapted by the author

The components presented in Figure 2 do not need to be complied with in the order presented, everything will depend on the situation and on its 
managers, the important thing is to do these analyzes continuously because they are different in every moment, arising situations that need to be monitored separately. The content of each component shown in Figure 2 represents:

A- Analysis of the strategic situation: The starting point for the strategic plan creation is to make an analysis, diagnosis or evaluation of the strategic situation. The main items to be considered in the strategic situation analysis are: the mission or the organization's business and the organization's performance - results achieved compared with the established goals (Maximiano, 2008). The mission or organization's business comprises answering some questions, such as who are our customers? What kind of business are we in? What needs are we fulfilling? What is our usefulness to customers? The mission is the perception reflection of opportunities and threats of the values of your organization and your vocation (Maximiano, 2008).

The fundamental strategic planning cornerstones of an organization are shown in Figure 3: vision, mission and values. The vision is the organization's future aspirations, it cannot be a delirium, and it must be built with concrete objectives in the long term, in a period that varies between 10 to 15 years. As from its definition, the actions in the present time start to be drawn. In turn, the mission of a company is its reason for being, it is the soul of the company, and it is the reference in the guidance for the planning implementation. The values represent the essence of the company, which is demonstrated in its actions and attitude towards business. The strategy means the plans to be drawn to achieve the objectives set forth by the vision.

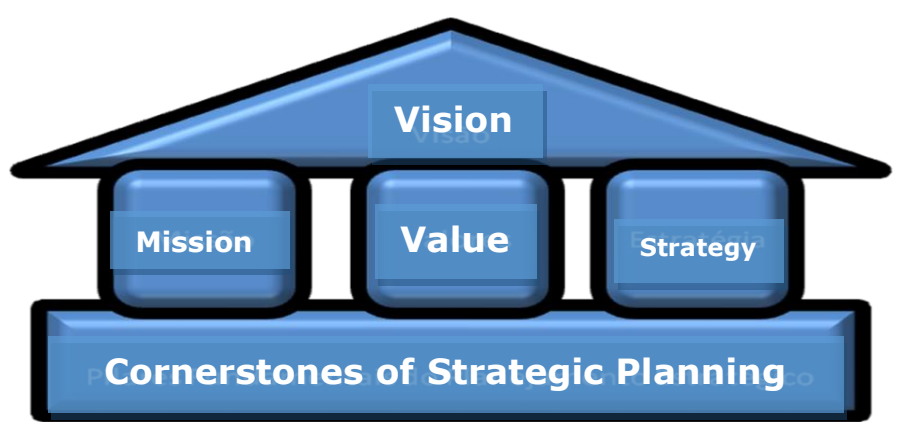

Figure 3: Fundamental Cornerstones of a Strategic Planning

Source: Prepared by the author 
Performance analysis will serve not only as a basis to check the results obtained with the proposed objectives, but also to analyze the competition, serving in the identification of the strengths and weaknesses of the organization. Some key factors that can be analyzed are: customer participation in revenues, products and services participation in revenues, market participation and analysis of competitive advantages (Maximiano, 2008).

B- Environmental analysis: for Almeida (2001, p.23), the environmental analysis is, in general terms, the more complex and important stage of a strategic plan, it is when organizations envision the opportunities and threats presented by the environments that surround them.

In Table 1, Almeida (2001, p. 23) classifies the environments that permeate an organization.

\begin{tabular}{|c|c|c|}
\hline $\begin{array}{l}\text { Environmental } \\
\text { segment }\end{array}$ & Environmental variables and their characteristics & Analysis Techniques \\
\hline $\begin{array}{l}\text { Climate } \\
\text { Macro-environment }\end{array}$ & $\begin{array}{l}\text { The macro environment climate variables are connected to } \\
\text { actions of all the government bodies. The actions can cause } \\
\text { direct impact on the organization, such as specific legislation, or } \\
\text { may cause indirect impact, such as inflation. The main variables } \\
\text { are inflation, interest rates, legislation, GDP and other related to } \\
\text { political power. The predictability of an organization macro } \\
\text { environment climate is similar to the physical climate prediction } \\
\text { in which the short-term forecast and the long-term trends can be } \\
\text { made with some accuracy. As the macro environment climate } \\
\text { forecast is uncertain it is up to the planner to opt for a scenario } \\
\text { from among the several possible. }\end{array}$ & $\begin{array}{l}\text { Opinion of experts, } \\
\text { brainstorming } \\
\text { technique. }\end{array}$ \\
\hline $\begin{array}{l}\text { Soil } \\
\text { Macro-environment }\end{array}$ & $\begin{array}{l}\text { The soil macro-environment variables are connected to the study } \\
\text { of the population trends and their characteristics. It is } \\
\text { noteworthy for example, the growth or reduction trend by } \\
\text { income, education level, age, region or gender. The predictability } \\
\text { of the soil macro environment variables is more accurate and can } \\
\text { often boils down to the trends extrapolation. }\end{array}$ & $\begin{array}{l}\text { Trends extrapolation, } \\
\text { exponential forecasts. }\end{array}$ \\
\hline $\begin{array}{l}\text { Operational } \\
\text { Environment }\end{array}$ & $\begin{array}{l}\text { The operational environment analysis boils down to visualizing } \\
\text { how the organization will interact with customers, competitors } \\
\text { and suppliers in the future according to the financial, commercial, } \\
\text { technological matters and others. }\end{array}$ & $\begin{array}{l}\text { Scenarios, models } \\
\text { simulation, causal } \\
\text { models, Delphi } \\
\text { projections, cross- } \\
\text { impact analysis, } \\
\text { morphological analysis. }\end{array}$ \\
\hline $\begin{array}{l}\text { Internal } \\
\text { Environment }\end{array}$ & $\begin{array}{l}\text { In this segment, it is sought to meet the aspirations and values } \\
\text { of the people in the organization and the people who have } \\
\text { relationship with it. In the past, little was the importance given to } \\
\text { the values and aspirations of employees when drawing up the } \\
\text { organizations strategies, which were focused on meeting the } \\
\text { interests of only the shareholders. Today, most organizations } \\
\text { are focused on meeting the interests of the group of people who } \\
\text { benefit from it (stakeholders): shareholders, customers, } \\
\text { suppliers, employees, community, among others. }\end{array}$ & $\begin{array}{l}\text { Analysis of } \\
\text { organizational culture. }\end{array}$ \\
\hline
\end{tabular}

\section{Table 1: Environmental Classification}

Source: Almeida (2001, p. 23) 
When studying the external environment, the organization analyzes all the elements that may influence its activities and its performance and thus, seize the opportunities and avoid the threats that these environments present. The internal environment analysis, in turn, helps the organization to identify its strengths and weaknesses, and through this analysis, identify factors that may pose threats and / or opportunities in the external environment.

C- Definition of strategic objectives: It is understood by strategic objectives the target to be reached by the company in a given period. The objectives should be represented with perspicuity, technical and economic feasibility, prioritize the needs and be coherent with the organization's mission (Oliveira et al., 2011). According to Maximiano (2008, p. 105),

The strategic objectives define the desired results for the entire company in the long term. The strategic objectives cover areas of the performance such as market position, turnover, innovation, social responsibility and image in the community, human resources competences, value and efficiency of physical resources, investments and overall financial results, among others. The strategies are always associated with strategic objectives, the results that the company intends to accomplish.

D- Functional and operational strategies: Operational strategies are connected to the specific operations, such as the mobilization and the funds availability. As for the functional strategies they are related to the qualification of non-operational areas such as adoption of organizational management techniques or even partnership with distributors (Oliveira et al., 2011).

E- Execution and evaluation: According to Oliveira et al. (2011, p. 42), "[...] to execute the strategy, the implementation demands leadership, organizational structure and management systems that lead to the commitment and to the coordination of all employees as well as to the resources mobilization".

The strategic evaluation lists the criteria to be analyzed, such as the efficiency to reduce or eliminate vulnerabilities and external threats, maximize resources and explore opportunities of the external environment (Oliveira et al., 2011). 
As noticed, the analysis on the constituent elements of the strategic process may allow any kind of company to guide its actions in search of its business objectives in a systematic and organized manner.

\subsection{TOOL BALANCED SCORECARD (BSC)}

There are plenty of tools to control and evaluate / measure if the deployed strategies are presenting the desired effects. One way to conduct such analyzes is the use of the Balanced Scorecard technique developed at Harvard University by Professor Robert Kaplan and the executive David Norton, originally drafted as a "comprehensive tool which reflects the vision and the company's strategy into a coherent set of performance measures "(Maccari, Lobosco \& Souza, 2009).

According to Kaplan and Norton (1997, p. 2)

This tool reflects the mission and the strategy of companies in a comprehensive set of performance measures that provides the basis for a strategic measurement and a management system. The Balanced Scorecard continues to emphasize the pursuit of financial objectives, but also includes the performance drivers of those objectives. The scorecard measures the organizational performance under four different balanced perspectives: financial perspective, the customer perspective, the internal business processes perspective and the learning and growth perspective. The Balanced Scorecard allows companies to follow up the financial performance, monitoring at the same time, the progress in the building of capacity and the acquisition of intangible assets needed for future growth.

According to Maccari et al. (2009), the use of this tool by companies, especially by small companies in expansion, assists in the strategic controls definition offering indicators and performance measures that can provide to the organizations the achievement of strategic objectives previously formulated. Small companies, in their large majority, do not have technical staff specialized in administrative tools and so, they carry out their controls in a rudimentary way. The BSC insertion may facilitate the controls ordering towards these objectives, as well as the formulation of new strategies.

The BSC was a proposal presented by its creators as a tool which structures the organization, evaluating the result through the financial indicators and representative non-financial indicators (Scattolini, 2007). 


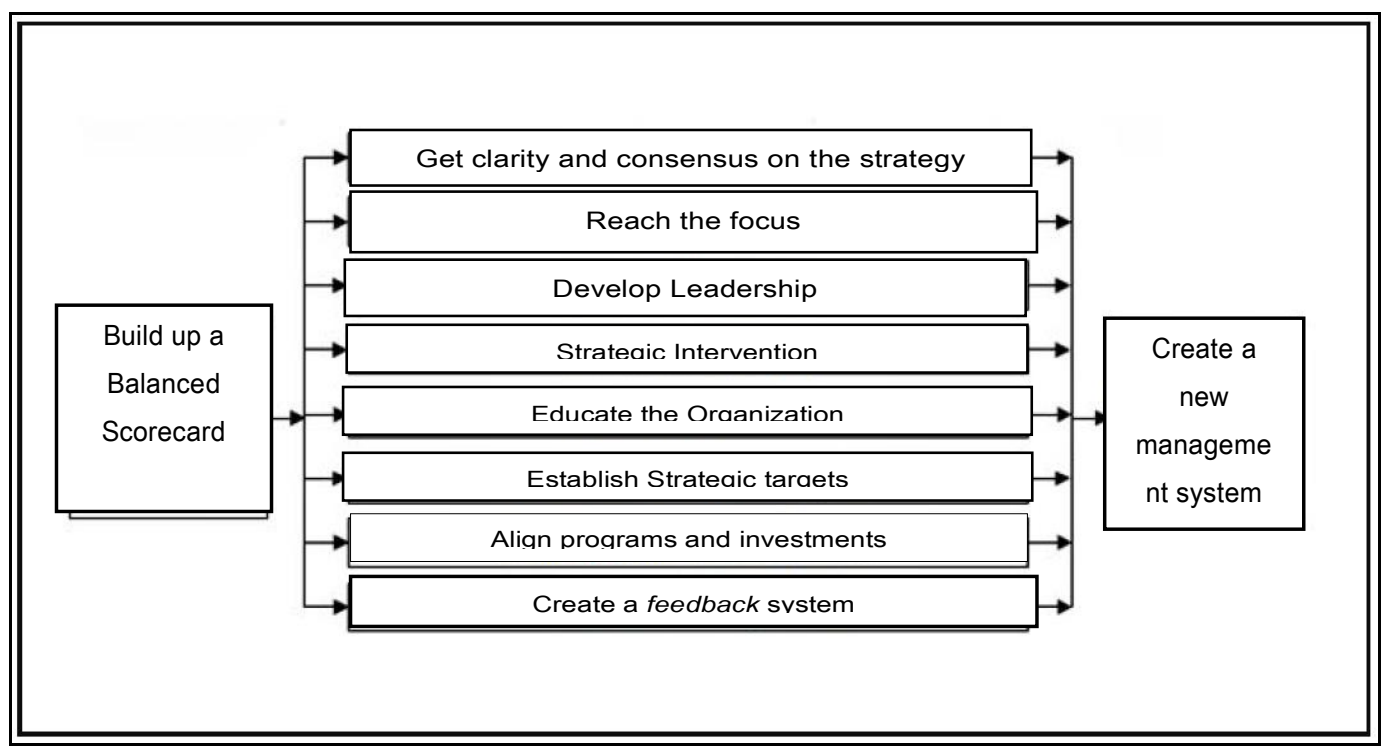

Figure 4: Reasons for an organization to draw up a Balanced

\section{Scorecard}

Source: Kaplan and Norton (1997 p. 286).

Figure 4 presents the reasons pointed by Kaplan and Norton (1997, p. 286) to build up the BSC and create a management control system which will be able to provide success in achieving the organization desired goals.

The BSC in literal translation means "balanced performance indicators"; the term balanced is connected to four different perspectives interacting with each other. Each of them progresses to specific measures and by indicators, as highlighted by Maximiano (2010, p. 365):

- customer perspective (How does the customer see us?);

- internal perspective (In which processes do we need to be efficient?);

- innovation and organizational learning perspective (How can we continue to improve and to create added value?);

- financial perspective (How do we serve the shareholder interests?). 


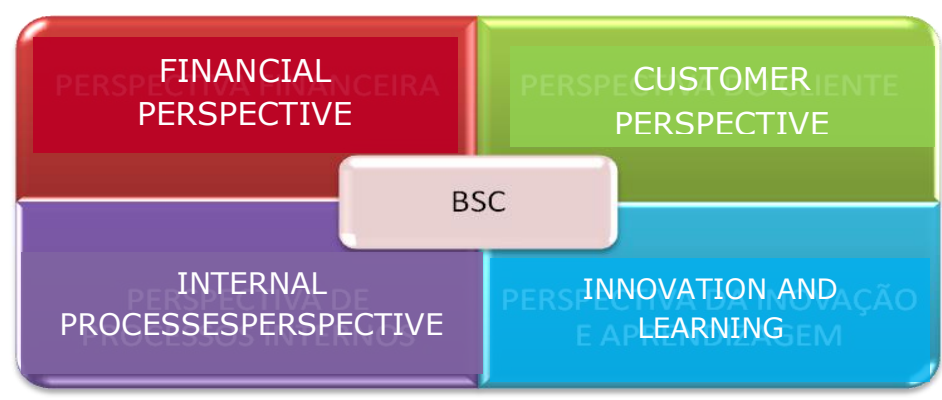

Figure 5: The Balanced Scorecard - four dimensions of an organization's performance

Source: Maximiano (2008) adapted by the author

The four perspectives proposed by Kaplan and Norton (1997) for the BSC construction will be analyzed below.

\subsubsection{Innovation and organizational learning perspective}

Kaplan and Norton (2004, p. 203) define:

The learning and growth perspective of the Balanced Scorecard emphasizes the importance of aligning the intangible assets with the organization's strategy. This perspective contains the objectives and indicators of the three components of the intangible assets, essential for the strategy implementation: 1. Human capital; 2. Information capital; and 3. Organizational Capital. The objectives of these three components must be aligned with the objectives of the internal processes to each other. The intangible assets should be based on the capabilities created by other tangible and intangible assets, instead of developing independent capabilities without synergies among them.

This perspective is connected to the employees and to the internal management improvement through managerial practices and use of information technology. The learning and growth perspective is aimed at the infrastructure that the company should have to generate growth and improvement in the short and in the long-term (Maccari et al., 2009). 


\subsubsection{Customer Perspective}

According to Kaplan and Norton (2004, p. 32),

The customer perspective defines the value proposition for the target customers. The value proposition provides the context so that the intangible assets create value. If customers value consistent quality and punctual delivery, the skills, the systems and the processes that produce and supply quality products and services are highly valuable to the organization.

This perspective enables executives to identify the customer segments and markets in which the business unit will compete as well as the unit's performance measures in these target segments. Among the essential results measures are: the customer satisfaction, the customer retention and the conquering of new customers, the customers' profitability and the participation in accounts (customers) in the target segments. But the customer perspective should also include specific value propositions measures that the company will offer to the customers of these segments. The customer perspective allows managers of business units to articulate the customers and markets strategies that will provide higher future financial profits, such as the fundraising and the profitability obtained through the customer satisfaction, fidelity and retention.

The customer perspective aims to inform the mission and the strategy approached by the company in order to identify the potential customers, the specifications to be met and the market segment (Igarashi et al., 2008).

\subsubsection{Internal processes perspective}

In accordance with Kaplan and Norton (1997, p. 25), this perspective identifies the critical internal processes in which the company must achieve excellence. These processes enable the business unit to offer the value propositions capable of attracting and retaining customers in 
target-segments of the market and satisfy the shareholders expectations, i.e. getting excellent financial returns.

The internal processes measures are focused on the internal processes which will have greater impact on customer satisfaction and on the achievement of the company financial objectives. In the internal processes objectives in the BSC, it stands out the processes that may not be currently running and that may be critical to the success of the company's strategy. Therefore, this perspective incorporates objectives and measures both for the long wave innovation cycle, and for the short wave cycle of operations.

The internal processes perspective aims to identify procedures that impact significantly on the strategy, such as innovations, investments in Research \& Development laboratory, new methods of production, product creation, etc. (Kaplan \& Norton, 2004). The internal processes perspective contributes to the organization alignment, promoting positive and significant impact on the company results.

\subsubsection{Financial perspective}

For Kaplan and Norton (2004, p. 32), "the financial perspective describes the tangible results of the strategy in traditional financial terms", such as profitability ratios, revenues growth and costs for products, cash turnover, among others.

The financial perspective shows the economic results achieved through the strategy developed by the company, that is, it checks the profitability achieved by the strategic planning, which impacts on the other perspectives.

According to Rock and Casartelli (2014), the financial perspective will allow to follow up the short-term financial indicators, adding the measures in the medium and long term for projecting the organization future results. A good performance of the financial objectives positively impacts on other perspectives. 


\subsubsection{BSC Performance Indicators}

In Table 2 below, it is presented objectives, functions and examples of indicators related to each of the perspectives suggested by Kaplan and Norton (1997), which can help organizations to achieve their strategic objectives.

\begin{tabular}{|c|c|c|c|}
\hline Perspectives & Objective & Functions & Example of indicators \\
\hline Customers & $\begin{array}{l}\text { Articulates the strategies in order to } \\
\text { provide greater future financial results. }\end{array}$ & $\begin{array}{l}\text { Identifies austomer and market segments in } \\
\text { which the company is able to compete and } \\
\text { define its performance measures in its target } \\
\text { segments. }\end{array}$ & $\begin{array}{l}\text { Customer acquisition. } \\
\text { Customer retention. } \\
\text { Customer satisfaction. }\end{array}$ \\
\hline $\begin{array}{l}\text { Internal } \\
\text { processes }\end{array}$ & $\begin{array}{l}\text { Focuses on identifying what needs to be } \\
\text { improved or created in order to meet } \\
\text { the attributes mapped in the customer } \\
\text { perspective. }\end{array}$ & $\begin{array}{l}\text { Directs the focus to the most aitical business } \\
\text { processes and identifies in which of them the } \\
\text { company needs to get excellence level in } \\
\text { relation to the achievement of customer and } \\
\text { shareholder objectives. }\end{array}$ & $\begin{array}{l}\text { Innovation. Rework. } \\
\text { Response time to the } \\
\text { customers. }\end{array}$ \\
\hline
\end{tabular}

Table 2 - Presentation of the objectives, functions and examples of indicators related to each of the perspectives proposed by Kaplan and Norton (1997)

Source: Igarashi et al. (2008)

As observed in Table 2, it can be created indicators and performance measures for a wide range of business sectors and for all and any type of industry or any sector an organization is in.

\subsection{STRATEGIC MAPS CREATION}

Kaplan and Norton (2004) define the strategic map as the strategy visual representation, making it possible to display on a page how the 
objectives in the four perspectives integrate and combine themselves into cause-effect relationships to describe the strategy.

According to Niven (2007), the strategic map communicates the strategy for everybody in the organization aligning the efforts and refining the developed actions. In addition, with the maps of the strategy, it is possible to manage through concrete information and not on instinct, because the tool helps to identify and to monitor the strategic objectives and the actions that add value to the corporate mission. Thus it represents the imperative connection between the strategy drawing up and its concrete accomplishment.

According to Kaplan and Norton (1997 apud Santos, 2011), "the strategic map is used in organizations to: i) clarify the strategy at the executive level; II) communicate the strategy to employees; III) align the units, departments, functions and initiatives; and IV) focus on the management processes".

Figure 6 presents an example of a strategic map.

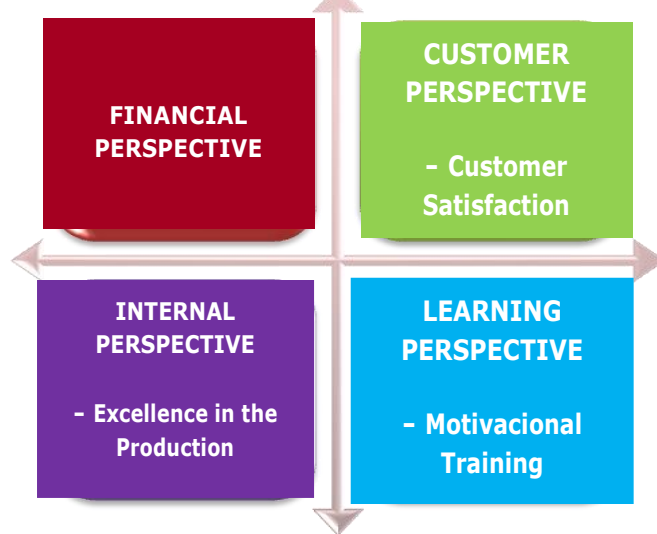

Figure 6: Strategic map example

Source: Adapted from Igarashi et al. (2008)

In Figure 6, it is presented some objectives by perspectives illustratively so that the organization employees can have a better viewing; it is the visual resource that the BSC can provide so that the team understands the main goals of its implementation. Through the map it is also possible, to identify and create intangible assets that add value to the organization as well as facilitators to generate competitive advantages. 


\section{RESEARCH METHODOLOGY}

This research was accomplished at the company Metadil Indústria e Comércio Metalúrgica Ltda, in the period from December 16, 2013 to January 12, 2014 in the areas of Finance, Human Resources, Customer Relations and Production, in order to analyze how the BSC tool assists the strategic planning of a small company in expansion stage.

To do this, a case study was carried out at the company. Ms. Marina Ximenes Rodrigo Amaral, who holds the position of Director at Metadil, was interviewed to identify the main aspects of the strategic planning and thus identify how the BSC tool was inserted in the organization for helping it achieve its objectives. The methodology used in this study is described below.

To meet this research purpose, it was adopted as methodology a descriptive exploratory research formulation, through a semi-structured interview, individual and in depth. It is noteworthy that this type of interview is a methodological resource that seeks, based on theories and assumptions defined by the researcher, to collect responses from the experience of a source, selected because this source holds information that is desire to be known.

The type of research adopted was the qualitative one, since, according to Kauark, Manhães and Medeiros (2010, p. 26-27), it is considered that there is a dynamic relationship between the real world and the subject, in other words, an inseparable bond between the objective world and the subject subjectivity that cannot be translated into figures. The phenomena interpretation and the meanings assignment are basic in the qualitative research process, which does not require the use of methods and statistical techniques. The natural environment is the direct source for data collection and the researcher is the key instrument. In this research descriptive - researchers tend to analyze their data inductively. The process and its meaning are the main focuses of approach. Qualitative research deals with phenomena, events whose meaning only exists on a private and subjective sphere, as is the case of this research. 
As to the objectives, this research is of exploratory-descriptive type, since, according to Kauark, Manhães and Medeiros (2010, p. 28), it aims a greater familiarity with the problem, making it explicit, or the hypotheses construction. It involves bibliographical survey; interviews with people who have had practical experience with the researched problem; analysis of examples that encourage the understanding. It assumes, in general, the bibliographical research and case studies forms.

Regarding the technical procedures in this research it was used bibliographic searches, document analysis and case study in depth, following the precepts of Yin (2010), used when it comes to deep and comprehensive study of one or a few objects, so that it is allowed its wide and detailed knowledge. Regarding the sample, it was done in an intentional and non-probabilistic way due to the easiness of accessing the Metadil Company and due to the easiness of its data access by the researcher. The interview method in depth was used with open and closed questions.

It was opted for the use of case study, due to the fact that this kind of analysis turns the results more robust results and, keeping its peculiarities, are capable of generalization (Herriott \& Firestone, 1983). This case study technique has been developing over the years. Authors such as Yin (1981, 1984, 1994, 2003), and Waters Mintzberg (1982), Eisenhardt (1989), among others, have studied and improved this technique. Currently, this method has been used in the most diverse situations, especially when one wants to better understand a phenomenon and its interrelations with the object under study.

According to Yin (2010), through this method, multiple dimensions of a theory can be seen, comprehensively, in a real case. The author also explains that such a search strategy is applied when it is intended a wide exploration and the study object characterization and, also when its characteristics are not easily found in other samples, and also when investigating contemporary phenomena within a real context.

For data interpretation, Miles and Huberman (1994) propose an analysis model in the qualitative investigation consisting of three stages: data reduction, data presentation, conclusions and verification. 
The data reduction of refers to the process of selecting, simplifying and organizing all the data obtained during the investigation; transcription of interviews and coding.

The data presentation refers to the time the information is organized and compacted, to thereby the investigator be able to view quickly and effectively what happens in the study; identify the theme and the data found.

The third and last moment corresponds to the conclusions extraction of all the information gathered, organized and compacted, which is dependent on the quantity of taken notes, of the methods used, and especially on the researcher's experience in this field; on the hypothesis testing and on the delimitation, in profound way, of the structure.

Thus, the data collected in the interviews were analyzed using qualitative techniques of content analysis, which allowed making a clear and detailed description on the use of the BSC tool on each of its perspective and the results of its implementation for the definition of indicators and performance measures and to create controls in the organization.

\section{THE CASE ANALYSIS}

The case study of the company Metadil Indústria e Comércio Metalúrgico Ltda was carried out through interviews with the director of the financial management area, Marina Ximenes Rodrigo Amaral, with the aim of identifying how the strategic plan is prepared by the company using the BSC and thus suggesting the possible use of this tool by small companies in expansion stage, contributing in a way that they can achieve their organizational objectives. This company BSC is viewed through a strategic map presented in this case analysis.

Metadil is a Brazilian, private closely-held company, founded in 1974, a school furniture manufacturer. Its products are certified by the standardization rules of ABNT (Brazilian Agency for Technical Standards), for ergonomic appraisal reports, and owns the FSC (Forest Stewardship Council), which attests the handling according to the principles of preservation and sustainability and increases reliability, ensuring high 
standards for quality products and customers credibility. Its headquarters is located in Guarulhos (São Paulo) and it has representatives in the states of Amazonas, Pará, Maranhão, Piauí, Ceará, Rio Grande do Norte, Paraiba, Pernambuco, Sergipe, Bahia, Goiás, Minas Gerais, Rio de Janeiro, Espirito Santo , Rio Grande do Sul, Paraná, São Paulo and the Federal District.

According to the interviewed manager, in order to achieve its strategic objectives, the company started to use the BSC tool to prepare the strategic planning and, especially, to assist in the creation of indicators and performance measures. With the expansion and the customer portfolio increase and the consequent production increase, Metadil sought control tools that would enable it an actual follow-up of the company and for such a task this tool was chosen.

Currently the company's planning is done for a period of one year, with board meetings outlining goals and approaches to be formalized. The external environment is often analyzed, especially the competitors. The company manufactures furniture for public and private education institutions, but it still does not consider a threat, the increasing availability of distance learning courses and a reduction in the demand for its products because the specific audience of the company are the elementary and secondary schools where teaching is practiced in person, presentially.

The internal environment analysis, in turn, occurs when the company detects problems in its organizational structure or where there are conflicts among its employees. This role is played by the supervisors in each area and by the company's directors, with the support of the organization's Human Resources Department.

For this case analysis, it was opted to describe the use of the BSC in the company already inserted in its four perspectives.

For the financial perspective, in the last planning, indicators and performance measures were outlined so that the revenues had a $10 \%$ increase compared to the last period and that there were also cost reductions for the company. It is under implementation the presentation of the objectives to the employees, through videos and the strategic map display that point to the strategy to be adopted by the company so that it achieves these goals. 
In the perspective of internal processes, the company perceived the need to improve some processes and the organizational structure. To do so, it is under analysis by the organization, the deployment of the ISO standards, specifically the ISO 9001, to guarantee the quality of its products to the customers, the processes automation and also the production increase.

The brand and the products disclosure is made to the entire customer portfolio through informative e-mail. Another way to disclose the products and the 'Metadil' brand is through inserting ads in specialized magazines, social network, in the company's own website and mainly through customers' indication. In the company, it is constantly sought a close relationship with its customers, by carrying out satisfaction surveys to understand the needs of each one and the points to be reviewed and possibly enhanced, making retention and fidelity of clients achievable. These indicators were upgraded with the use of indicators proposed by the perspective of the BSC costumers.

In the learning and growth perspective, as the school furniture business has its sales peak in the school vacations period to facilitate the professionals displacement and the exchange of such equipment without harming the classes progress and not running the risk of accidents to the students and teachers, these institutions constantly seek not only innovations for the creation of products, but also meet the specific customers needs. This is all done to balance out the seasonality in sales. Thus, in its industrial courtyard there is a department / laboratory where new products and special products are designed and tailored to meet the needs of these specific customers. It is the role of the company's Human Resources, with the assistance of supervisors of other sectors, to improve and qualify its employees. One of the ways the company uses for this is providing specialized courses and monthly fee reimbursement assistance of undergraduate degree and / or graduate degree courses in which employees possibly enroll.

Indicators on learning and organizational growth have been implemented to identify how many innovations were originated from the employees' ideas, what training sessions and courses were made available 
by the company. It was also analyzed the academic and professional training of its workforce and the amounts invested in the payment of courses held by the company as well as the next foreseen training courses to enhance enterprise activities and its innovation process.

To illustrate the company strategic planning using the BSC tool, the strategic map demonstrating the organizational objectives of the period is presented on the bulletin boards to its employees, as presented in Figure 7 below.

\section{FINANCE PERSPECTIVE}

- Increase revenues in $100 \%$;

- Minimize costs.

$\begin{array}{ll} & \text { CUSTOMER PERSPECTIVE } \\ \text { - } & \text { Fidelize customers; } \\ \text { - } & \text { Minimize costs. } \\ \text { - } & \text { Keep punctlence in serving } \\ & \text { INTERNAL PERSPECTIVE }\end{array}$

- Acquire the ISO 9001 seal;

- Ensure the products high quality;

- Increase the production work load

- Automate administrative processes.

\section{LEARNING PERSPECTIVE}

- Employee empowerment;

- Make the HR more active in the company;

- Promote relationship, health and welfare lectures to motivate employees.

\section{Figure 7: Metadil Strategic map}

Source: Prepared by author

Figure 7 presents the BSC strategic map. In it one can observe the main strategic goals of the company through the BSC perspectives, the company financial objectives, what is expected from the customer service areas; which internal processes will be able to help in the generation of high quality products and consequently afford the satisfaction of its customers and, ultimately, the investments to be made as to the organization learning and growth aiming at the continuous improvement of its staff.

At Metadil strategic map, it is pointed out some aspects to be improved, mainly in the interaction among departments. With this tool, it is possible to assist the organization regarding the identified weaknesses 
along the way, aligning the financial indicators to the nonfinancial ones so that thereby the organization get satisfactory return on the investments made.

\section{FINAL CONSIDERATIONS}

In the article it was analyzed the use of the BSC tool in the strategic planning of small companies in expansion stage, as is the case of this study conducted at Metadil company, and the BSC's contribution to the achievement of its organizational objectives. When this tool is deployed correctly by the organizations it can bring benefits, meeting the organization expectations in favor of the desired results.

The BSC helps in identifying and troubleshooting after deployment of the strategies, alignment and focus on goals, turning the strategy into procedures and tasks for everyone in the organization (Kaplan \& Norton, 2004).

As the deployment of the BSC tool is still in embryonic phase at Metadil Indústria e Comércio Metalúrgico Ltda, there are some aspects to be enhanced, such as interaction among departments, make crystal clear to employees about the importance of commitment and performance of each one of them to reach the business success, cost and expenses analysis in order to reduce wasteful spending and ensure the company economic and financial sustainability.

So that the BSC deployment is successful, it is needed the involvement of all departments, the process control and monitoring, generating feedback to intervene at the right time, creating a strategic route.

An important point to be highlighted is that everyone in the organization must be committed and willing to use the BSC to the effectiveness of the goals. To carry out internal modifications, all company departments should be involved, working in synergy for the benefit of the organizational objectives and not just with the aim of creating the 
strategies, monitor and control, so that if some area is not reaching the expected results the responsible sector assumes responsibility, correct the possible deviations and set new targets for achieving the goals.

Thus, the BSC deployment at Metadil helped managers and employees to overcome the weaknesses, to maximize the strengths, since this tool aligns the strategies, the execution and the evaluation of the planning, not allowing that a problem or happening influences the course and the achievement of goals.

The BSC tool helped the company to create indicators and performance measures by areas, focusing on the need of each manager and simultaneously aligning these areas to the strategic planning. The BSC tool afforded presenting to all the organization employees a summary of the main corporate objectives through the development of its strategic map.

Whenever the BSC is deployed correctly it becomes a factor for differentiation and can provide an interesting competitive advantage. A company does not change completely just because it used this tool, but, according to the analysis, when an organization works towards achieving the company's results, such results become satisfactory.

Therefore, the aim of this study was achieved because it was found that the BSC tool can assist in the strategic planning of a small company in expansion phase, involving all the departments, generating controls and fast turnaround of the facts occurred, uniting financial and not financial indicators as demonstrated in this study.

\section{REFERENCES}

Ackoff, R. L. (1974). Planejamento empresarial. Rio de Janeiro: Livros Técnicos e Científicos.

Almeida, M. I. R. (2001). Manual de planejamento estratégico. São Paulo: Atlas.

Eisenhardt, K. M. (1989). Building theories from case study research. Academy of Management Review, 14(4), 532-550. 
Fillion, L. J. (1999, abril/junho). Empreendedorismo: empreendedores e proprietários-gerentes de pequenos negócios. Revista de Administração da Universidade de São Paulo (Rausp), 34(2), 5-28.

Fischmann, A. A., \& Almeida, M. I. R. (2009). Planejamento estratégico na prática. São Paulo: Atlas.

Hayden, C. (1986). The handbook of strategic expertise. New York: The Free Press.

Herriott, R. E., \& Firestone, W. A. (1983, February). Multisite qualitative policy research: optimizing description and generalizability. Educational Research, 12(2), 14-19.

Hisrich, R. D., \& Peters, M. P. (2002). Entrepreneurship. New York: McGraw Hill.

Hitt, M. A., Ireland, R. D., \& Hoskisson, R. E. (2001). Strategic management: Competitiveness and globalization. Cincinnati, Ohio: South-Western College Publishing.

Igarashi, D. C. C., Igarashi, W., Gasparetto, V., \& Martins, K. R. G. (2008, maio/agosto). Mapa estratégico e painel de desempenho: um estudo numa empresa da grande Florianópolis. Enfoque: Reflexão Contábil, 27(2), 9-20.

Kaplan, R. S., \& Norton, D. P. (1992, January-February). The balanced scorecard - measures that drive performance. Harvard Business Review, 70(1), 71-79.

Kaplan, R. S., \& Norton, D. P. (1997). A estratégia em ação: balanced scorecard. Rio de Janeiro: Campus.

Kaplan, R. S., \& Norton, D. P. (2004). Mapas estratégicos (4a ed.). Rio de Janeiro: Campus.

Kauark, F., Manhães, F. C., \& Medeiros, C. H. (2010). Metodologia da pesquisa: guia prático. Itabuna: Via Litterarum.

Lacombe, F. J. M. (2009). Teoria geral da administração. São Paulo: Saraiva.

Maccari, E. A., Lobosco, A., \& Souza, N. (2009). A importância da ferramenta balanced scorecard para a análise financeira da empresa um estudo de caso na empresa Duratex. Anais Seminários em Administração - SemeAd, 12, São Paulo, SP, Brasil.

Maximiano, A. C. A. (2008). Teoria geral da administração (6a ed.). São Paulo: Atlas.

Maximiano, A. C. A. (2010). Introdução à administração. São Paulo: Atlas. 
Miles, B. M., \& Huberman, A. M. (1994). Qualitative data analysis: an expanded sourcebook (2nd ed.). California: Sage.

Mintzberg, H. (2008). Criando organizações eficazes: estruturas em cinco configurações (2a ed.). São Paulo: Atlas.

Mintzberg, H., \& Waters, J. (1982). Tracking strategy in an entrepreneurial firm. Academy of Management Journal, 25(3), 465-499.

Niven, P. R. (2007). Balanced scorecard aasso-a-passo: elevando o desempenho e mantendo resultados. Rio de Janeiro: Qualitymark.

Oliveira, L. M., Perez Jr., J. H., \& Silva, C. A. dos S. (2011). Controladoria estratégica ( $8 a$ ed.). São Paulo: Atlas.

Porter, M. (2004). Estratégia competitiva. Rio de Janeiro: Elsevier Brasil.

Rocha, J. M., \& Casartelli, A. de O. (2014). Análise do processo de implantação do Balanced Scorecard (BSC) em uma instituição de ensino superior. Revista Gestão Universitária na América Latina-GUAL, 7(3), 268-290.

Rosa, S. E. S., Correa, A. R., Lemos, M. L. F., \& Barroso, D.V. (2007, março). O setor de móveis na atualidade: uma análise preliminar. BNDES Setorial, 25, 65-106.

Santos, M. O. G. (2007). Mapas estratégicos - Texto de apoio. Évora, 2011. Scattolini, R. (2007). Uso do Balanced Scorecard como direcionador da tecnologia da informação. Dissertação de Mestrado, Escola Politécnica da Universidade de São Paulo, SP, Brasil. Recuperado em 3 de dezembro, 2013, http://www.teses.usp.br/teses/.../3/.../Renata_Scattolini_Dissertacao_Fi nal.pdf

Souza, S. C. de, \& Marinho, S. V. (2014). Planejamento estratégico baseado no balanced scorecard: um estudo de caso aplicado a uma pequena empresa de segurança. Gestão \& Planejamento-G\&P, 15(2), 213-237.

Yin, R. K. (1981, March). The case study crisis: some answers. Administrative Science Quarterly, 26(1), 58-65.

Yin, R. K. (1984). Case study research. Beverly Hills: Sage.

Yin, R. K. (1994). Evaluation: a singular craft. In C. Reichardt, \& S. Rallis, New directions in program evaluation (pp. 71-84). San Francico: JosseyBass.

Yin, R. K. (2003). Case study research: design and methods (3rd ed.). Thousand Oaks: Sage.

Yin, R. K. (2010). Estudo de caso: planejamento e métodos (4a ed.). Porto Alegre: Artmed. 